\title{
Poetika antižurnalizma u esejima A. B. Šimića
}

Jela Sabluí́ Vujica

Filozofski fakultet

Matice hrvatske b.b.

$\mathrm{BiH}$ - 88000 Mostar

E-pošta: jela.sabljic.vujica@gmail.com
UDK: 821.163.42.09-4 Šimić A. B. Izvorni znanstveni rad Primljeno: 18. travnja 2018. Prihvaćeno: 30 . svibnja 2018.

\section{Sažetak}

Šimićev esejistički rad karakterizira uporaba kritičkih, polemičkih, programatskih i aforističkih sredstava u jednoznačnoj afirmaciji ekspresivne naravi umjetničkoga bića i jednoznačnoj negaciji poetičke svrsishodnosti i etičkoga tradicionalizma. Jednoznačnost kritičkih i poetičkih iskaza upućuje na tendencijski ustroj Šimićeva diskursa. Ovaj se ustroj najjasnije očituje u Šimićevu antagonističkom stavu prema pojmu i modelu žurnalizma koji se u autorskoj perspektivi otkriva kao isključivo namjenska vrijednost. Koristeći dijalektičke uvide kritičke teorije, osobito one Habermasove, povijesne i filozofske uvide Blocha, Foucaulta, Kosellecka, te književnoteorijske uvide Terry Eagletona, u ovom će se radu nastojati ukazati na povezanost načelne i namjenske vrijednosti modernoga diskursa kao presudne činjenice, kako u poimanju i oblikovanju Šimićeve poetike antižurnalizma, tako i u poimanju i oblikovanju modernoga diskursa uopće.

Ključne riječi: antidogmatizam; antižurnalizam; kritika; modernizam; poetika. 
Tražiti dokaze Šimićevih stvaralačkih nazora u dosljednosti izraza ili uvjerenja znači ići pogrješnim putem. Šimić je matoševac koji to, po vlastitome priznanju, prestaje biti sa 17 godina. ${ }^{1}$ On je ekspresionist, koji bi radije da ne bude ubrojen u to društvo, ${ }^{2}$ on je radikal, stavovi koje primjerice izriče u Slobodi ljubavi znatno premašuju liberalno njegovani ukus današnjice, ${ }^{3}$ pa ipak odlučno odbacuje revolucionarno nebo kao tuđinsko. ${ }^{4}$ Usto je i odmetnik, izgubljeni sin, polemičar, prokleti pjesnik. ${ }^{5}$ Piše: "Moj je problem vrlo jednostavan, ali nerješljiv... Svako građansko zvanje, koje bi ja mogao dobiti, ne samo da bi bilo za mene poniženje, nego je protiv moje savjesti", ${ }^{6}$ ali ove oznake, priznaje pjesnik, imaju vrijednost samo kao načelo osobnoga razvitka - taj je A. B. Šimić A. B. Šimiću samomu dalek i gotovo tuđ.7

1 "Kad sam, 1915. došao u Zagreb, u svojoj 16. godini, bio sam još uvijek matoševac; i još godinu dana otprilike." Antun Branko Šimić, "Ekspresionizam i svečovječanstvo", u: Sabrana djela, Proza II, August Cesarec, Zagreb, 1988., str. 318.

2 Isto.

3 Riječ je o neobično napregnutomu tekstu iz 1923. godine. Šimiću je dovoljna tek jedna varijacija osnovne teme da pogodi ustaljeni poredak društvene sfere. Evo kako u jednoj rečenici dijalektički razotkriva prisilu većinske logike: "Dakle, zahtjev jedne društvene većine koja još uvijek, bilo iz religioznog uvjerenja bilo iz najobičnije konvencije, ne može da uđe u bračni život bez popa, da to isto mora da čini i društvena manjina, nije ničim opravdan; jednako što ne bi bilo opravdano da društvena manjina zahtijeva da se društvena većina pokorava njenom uvjerenju, ukusu itd. (makar bi ovaj zahtjev bio manje apsurdan, svakako)." A. B. Šımıć, "Sloboda ljubavi", u: Sabrana djela, Proza II, August Cesarec, Zagreb, 1988., str. 472-473. Upravo posljednja rečenična klauzula, zagrađena i osnažena modalnom česticom, ukazuje na Šimićev svjetonazorski prodor.

4 Papirići predstavljaju niz razasutih zapisa koji se postupno zgušnjavaju u sentence i gnome. Ono što izaziva pozornost jest izvrtanje samoga postupka sažimanja koji, umjesto jesne ili niječne konstatacije, ide izvana prema unutra, čime se pridružuje modernoj aforističkoj praksi i fragmentarnoj literaturi kakvu će stvarati Benjamin, Adorno, Bloch, Horkheimer. Tako se pukotine diskursa, kao primjeri otpora dovršavanju, izlažu umjesto da se prekrivaju. Evo primjera: "Nije da sam ja premalo revolucionaran, nego sve ono za što vi dižete toliku buku, vaš ideal, vaše nebo nije moj ideal, moje nebo: svaki čovjek jedan - bourgeois." A. B. Šımić, "Papirići", u: Sabrana djela, Proza II, August Cesarec, Zagreb, 1988.,str. 486.

5 Usp. Isto, str. 480-482.

6 A. B. Šımı́, "Radna bilježnica", u: Sabrana djela, Proza II, August Cesarec, Zagreb, 1988., str. 509.

7 Usp. A. B. Šımıć, "Papirići", str. 482. 
Sve su ovo svjedočanstva jednoga procesa. Moguće ih je legitimirati kao dokaz razvoja ili barem kao razvijanje dokaza. Radovan Vučković, u svakako najiscrpnijoj i najuvjerljivijoj studiji o Šimiću, ${ }^{8}$ govori o mijenama, preobražajima, fazama. ${ }^{9}$ Prva je faza matoševska, dominiraju duhovni pejzaži, žuta boja, otpor tradiciji. ${ }^{10}$ Matoš je, nesumnjivo, početna točka, i još više: referentno uporište, onaj od kojega se kreće i kojemu se utječe. ${ }^{11}$ Kao mistik estetskoga iskustva, Matoš je primjer neoboriva i nepotkupljiva angažmana, kao rabbi, on je primjer jasnoće, točnije rečeno, izražajne samosvijesti:

"Ta simpatija ondašnje mladosti za Matoša nije ništa čudnovato. Matoš je pisao najboljim, najjasnijim stilom onda. Matoš je bio duhovit, goleme erudicije, pročitao mnoštvo knjiga, putovao mnogo, proživio mnogo. Matoš je bio napadač, polemik, uvijek pobjednik. Matoš je, napokon, bio za sve slobode koje su drage mladosti; i zar on nije bio uvijek mlad, uvijek protiv roditelja, učitelja."12

Druga je faza ekspresionistička, dominira slobodan stih, plava boja, razaranje sintakse, umjesto otpora - raskid s tradicijom. Naravno, udio ekspresionizma u Šimićevu diskursu varira ovisno o perspektivi. Đuro Plemenčić piše: "Literarni historičar koji bude htio da sa svih strana osvijetli Šimićevu književnu fizionomiju, morat će da istraži

8 Usp. Radovan VučKović, Preobražaji i preobraženja (O Antunu Branku Šimiću), Svjetlost, Sarajevo, 1969.

9 Postoji cijeli niz varijacija na temu Šimićeva poetičkoga i kritičkoga razvoja. Zdenko Lešić govori o dvije razvojne faze i dvije poetike (usp. "A. B. Šimić", Izraz, XXIX, 3-4/1985., str. 149-184), Janez Rotar nalazi četiri faze (usp. "Iznenađujuća suvremenost poezije A. B. Šimića", Izraz, XX, 3/1976., str. 483-504), dok će Milanja naznačiti dvije poetike i tri faze (usp. Cvjetro Milanja, Pjesništvo hrvatskog ekspresionizma, Matica hrvatska, Zagreb, 2000., str. 48-49).

10 "Ta prva faza Šimićeva zaista je sva u znaku Matoša, pogotovo u kritici. U poeziji se, od prvih početaka do Vijavice (1917.), mogu lako pratiti i drugi utjecaji koji se uzgred asimilišu i postaju sastavni deo njegovog mladalačkog pevanja, a u kritici je jedan jedinstven: Matoš." R. VučKović, nav. dj., str. 27.

11 Matoš je egzemplar, i stoga stoji u prvome planu. Njegova je posvećenost egzemplarna, njegova je tragika egzemplarna, njegova je modernost egzemplarna. Šicel će, u emfatičkome tonu, napisati: "Na početku bijaše veliki mag književne riječi: Antun Gustav Matoš!" Miroslav Šicel, Antologija hrvatskog književnog eseja XX. stoljeća, sv. 1, Disput, Zagreb, 2002., str. 12. Bruno Popović će, u ispovjednom tonu, ("Ispovijest o Matošu"), napisati: "U svakom slučaju, Matoš nam je bio prvi i neosporni dokaz da smo nedužnom zaslugom književnosti doživjeli tragično otkriće istočnog grijeha nedovoljnosti stvarnog svijeta." Bruno Popović, Matoš i nakon njega, Razlog, Zagreb, 1972., str. 8.

12 A. B. Šimıć, "Ekspresionizam i svečovječanstvo", str. 319. 
neke utjecaje njemačkog ekspresionizma na njegovu poeziju."13 $\mathrm{Gu}-$ stav Krklec svjedoči: "Ne znam uopće ni da li bi se isplatilo uložiti mnogo truda i vremena da se 'fenomen' A. B. Šimića prikaže u njegovoj dijalektičkoj složenosti, pogotovo što njegovu pojavu književnoistorijski nije mogućno pravilno procijeniti bez poznavanja izvjesnih utjecaja strane književnosti, a osobito njemačke ekspresionističke lirike i zamašnog opusa bečkog satirika Karla Krausa."14

Šimićevu ekspresionističku književnu fizionomiju i fenomenologiju drukčije vide Jure Kaštelan, Vlatko Pavletić i Marin Franičević. U ukupnom fondu pjesnikovih strategija i postupaka oni će dakako uočiti ekspresivne elemente, ali nikako kao dominantne, a kamoli presudne za njegovu poetiku. ${ }^{15}$ Činjenica jest tek da je Šimić "njemačke i francuske tekstove čitao u originalu: na primjer berlinski časopis Der Sturm ili spis Kandinskoga O duhovnom u umjetnosti iz 1912."," i samim time: "Šimićeva se shvaćanja daleko više približavaju estetskim teorijama umjetnosti i likovnih umjetnosti oko 1910. godine, na primjer Worringerovim tezama... ili nazorima Kandinskog". ${ }^{17} \mathrm{Iz}$ njih pjesnik crpi slike i predodžbe umjetnosti kao pokreta nutrine, svojevoljnoga i odriješenoga predmetnih referenci. ${ }^{18}$ Šimić uči, usvaja, reproducira i stoga se njegov ekspresionistički nazor treba razu-

13 Đuro Plemenčić, "Antun Branko Šimić", u: Republika, br. 11-12, Zagreb, 1950., str. 826.

14 Gustav Krklec, "Zapis o Karlu Krausu", u: Novo noćno iverje, Veselin Masleša, Sarajevo, 1966., str. 174-175.

15 O relativnome udjelu i utjecaju ekspresionizma u Šimićevu stvaralaštvu usp. Vlatko Pavletić, "Beskompromisni kritičar", u: Književne novine, Zagreb, 1957., str. 9; Jure Kaštelan, "Antun Branko Šimić", u: Jure Kaštelan (prir.), A. B. ŠIMIĆ, Pjesme i proza, Zora - Matica hrvatska, Zagreb, 1963., str. 19; Marin FraniČEvić, "Antun Branko Šimić", u: Izraz, br. 2, Zagreb, 1966., str. 138-139.

16 A. H. ŽArković, "Uspomene o A. B. Šimiću i njegovom književnom krugu", u: Krugovi, sv. 5, Zagreb, 1955., str. 302.

17 Viktor ŽMegač, Težišta modernizma, SNL, Zagreb, 1986., str. 83.

18 I Worringerovu disertaciju i spis Kandinskoga, bez obzira na stanovite razlike u određenju pojma i naravi apstrakcije, moguće je razumjeti kao pokušaj rehabilitacije umjetničkoga patosa. Apstraktni uzorci boja, linija, pokreta ne samo da nadmašuju zbilju i njezine ograničene potrebe, nego korespondiraju s jednom instancom koja zadire dalje $i$ dublje od puko postojećega (usp. VASILIJ Kandinski, "O duhovnom u umjetnosti", u: Duh apstrakcije, MARCEL BAČıć (prir.), Institut za povijest umjetnosti, Zagreb, 1999., str. 143). Još se jednom, nakon romantizma, umjetnost inovira tako što se povlači iz svijeta. 
mjeti u pokretu, dakle evolutivno: on postoji i ne postoji u diskursu, dijelom je poetičke, a dijelom kritičke potrage, zauzima osobit položaj u prostoru i onda se napušta. ${ }^{19}$

Treća je faza u znaku Krausa, filozofije riječi, tehnike pjesme, odsustva boje, Bergsonova vitalizma. Stih se ponovo veže, ovaj put u organsku cjelinu, nazire se i određena kritička konstrukcija. Vučković će ovu fazu Šimićeva razvoja prepoznati kao konačno dosezanje zrelosti. No, ako se u obzir uzme razvojno načelo djela, a na njemu Vučković inzistira, nemoguće je odrediti granice razvoja, osim proizvoljno. Razvoj podrazumijeva kontinuirani rad, nikako prekid koji se onda može omeđiti, kontinuirano, a ne konačno dosezanje zrelosti. Sâm će Šimić napisati: "Stvarati - to je u najvišem i najponosnijem smislu mijenjati."20 Mijena se, kao stvaralačka instanca, opire naknadnomu određenju, i ne samo to, ona ga prisvaja, pretiče: njezinu najdubljemu i najskrivenijemu sadržaju pripada ono što se tek treba ostvariti. Zato se čak i kritička instanca mora uzeti s rezervom: "To sve, što sam napisao protiv gotovo svih starih i mladih književnika, novinara, slikara, ima se shvatiti kao nezadovoljstvo jedne mladosti onim što je oko nje. To ima samo vrijednost mojega ličnog razvitka."21

19 O evoluciji ekspresionističkoga pokreta vidi u: Walter H. Sokel, Der literarische Expressionismus, Albert Langen - Georg Müller, München, 1960. O evoluciji Šimićeva odnosa spram ekspresionizma, kako kritički tako i poetički, govore i Vučković i Žmegač. Vučković piše: "... evolucija ekspresionističkih pesnika išla je u pravcu smirivanja izražajne anarhije i retorsko-slikarskog eksibicionizma, u smeru naglašavanja konstruktivnog i kritičko-intelektualnog elementa u stvaralačkom procesu i u pesmi kao tvorevini intuicije i oštrog i racionalnog duha ujedno", R. VučKović, nav. dj., str. 151, dok će Žmegač ustvrditi: "Tko se uputio u složenost umjetničkih zbivanja epohe, tome se nameće zaključak da je ekspresionizam naziv za različite, dijelom vrlo raznorodne tendencije, pa da stoga paušalan sud ili čak definicija nisu mogući ni s tematskog i ideološkog ni sa stilističkog gledišta ... Ako je uopće moguće naći obuhvatnu karakteristiku ekspresionističkog pokreta treba je tražiti u društvenoj funkciji i u opoziciji ekspresionista svih boja i uvjerenja prema suvremenom građanskom svijetu." V. ŽMegač, nav. $d j$., str. 75. Drukčiju poziciju zauzima Milanja, umjesto o evoluciji, on će radije govoriti o transformaciji: "Uostalom sam je Šimić svoju zbirku nazvao Preobraženja, pa kolikogod da je donio sa sobom 'starih' konstituitivnih česti, i ma koliko da to bijaše proces, ipak se zbila transformacija, a ne samo puka evolucija, koja je 'pomicala' neke poetičke česti." C. Milanja, nav. dj., str. 60.

20 A. B. Šımıć, "Papirići", str. 482.

21 Isto. 
Ako bi se ipak pokušalo odrediti polove Šimićevih mijena, onda treba postupati krajnje svrsishodno. Treba mjeriti vidljive učinke njegova diskurzivnoga rada. Prema Kaštelanu, Šimićev se diskurs kreće između sukoba s tradicijom i pokušaja uspostavljanja novih kriterija, slično govori i Gordana Slabinac. ${ }^{22}$ No, Nemec, barem na konstruktivnome polu, uočava slabosti takva razgraničenja:

"I dok je prva, antitradicijska komponenta Šimićeve kritike - razumljiva u kontekstu avangardističkih težnji za prevrednovanjem svih vrijednosti i oslobođenjem od svih stega - dosljedno i jasno provedena, drugi je aspekt doista ostao samo na pokušaju i naznakama. Šimić, naime, nije razvio (ili, možda, nije stigao razviti) neki zaokružen kritički sustav, odnosno izgrađene i pouzdane vrijednosne kriterije. Strogo uzevši, on i nije kritičar, nego polemičar."23

Postaje jasno da se obuhvatnoj analizi Šimićeva diskurzivnoga rada stalno podmeću proturječni dokazi. Ne samo kako se ne mogu obuhvatiti nekim, barem privremeno stabilnim određujućim načelom, nego stalno rade jedan protiv drugoga. No, ako se, kao protumjera, pristupi analizi pojedinačnih ostvarenja, poteškoće se samo množe. Simićevi kritički, poetički ili ispovjedni tekstovi tek su vježbe koncentracije. Diskurs se na trenutak izoštrava, ritmički napinje do značenja, da bi se trenutak poslije rasplinuo u drugotnim, gotovo mehaničkim gestama. Čak je i ekonomija izraza lišena sugestivnosti. ${ }^{24}$ Sugestija je, dakako, sasvim suvremena kategorija: ako istina o stvarima izmiče, ako je pojmovni registar preuzak, preostaje iskušavati

22 Vidi u: Jure Kaštelan, "Približavanje", u: Približavanje: prolegomena za liriku Antuna Branka Šimića, Studentski centar Sveučilišta u Zagrebu, Zagreb, 1970., str. 100. O tome isto u: Gordana Slabinac, Hrvatska književna avangarda: poetika i žanrovski sistem, August Cesarec, Zagreb, 1988., str. 62.

23 Krešimir Nemec, Mogućnosti tumačenja, Hrvatska sveučilišna naklada, Zagreb, 2000., str. 111-112.

24 Iste karakteristike Milanja nalazi u Šimićevu pjesničkom jeziku. Kritika i poetika, prema Milanji, do te mjere korespondiraju da ih je moguće čitati istovremeno. Evo što Milanja piše o Šimićevim pjesmama nakon Preobraženja, osobito o ciklusu Siromasi i pjesmama iz razdoblja 1921. - 1925.: "Nema vizualnih slika ni 'bojanja', samo uprošćeni stil refleksije, a odsuće subjektnocentriranoga lirskoga ja znači objektivno viđenje svijeta i stvari." (C. Milanja, nav. dj., str. 91). Ipak, treba primijetiti da je tendencija reduciranja nazočna u Šimićevim esejima i ekspozitornim tekstovima i prije Preobraženja. Kritika ne samo da denotira poetiku, nego je i konotira. 
zvučne i slikovite registre. Preostaje iziskivati nijansu, kao posljednje neotuđivo utočište stvaralačke energije. ${ }^{25}$

U Šimićevim esejima ova instanca izostaje, i to im pridaje začudan karakter. Nema jarkih boja temperamenta, nema raskošnih ispita savjesti. Prizori su plošni, gotovo kubistički: "Dogodio se svijet okruglih tjelesa u prostoru, jedna kugla što se zove zemlja kruži, i na zemlji nešto dvolično: život nas i svih ostalih forma, i smrt nas i svih ostalih forma bez prekida, sve izvan naše volje." ${ }^{26}$ Ako se i može nazrijeti ritmički uzorak, u gradaciji, u ponavljanju, ako se mogu nazrijeti obrisi predmeta, makar tek sferično oblikovani, oni su odmah potom dokinuti u tjeskobnome prizivu nečega bez prekida, nečega izvan naše volje. Tako će naposljetku ostati samo prizori krajnje pokretljivosti i napetosti, naime usamljenosti, izgubljenosti, vriska: "Vrisak je danas jedini glas stvaralačkog Duha kulture, vrisak boli i vrisak bijesa. Vrisak, kojemu je tijelo riječ i zvuk i kamen i pokret i boja. Vrisak, jedini moguć da otvori uši ljudi koji ne znaju da postoji Duh."27

Šimićev diskurs ostaje prikovan uz ove prizore. Oni ne tvore širu sliku, niti ulaze u nove spojeve. Njihova transparencija nije jasnoća. "Mi ne znamo što je to umjetnost; to ne zna, uostalom, nitko do sada", ${ }^{28}$ piše u tekstu naslovljenome Namjesto svih programa. Na drugome mjestu

25 Prema Adornu, nijansa, kao najčišći jezični supstrat suvremenosti, nastaje i proteže se između rashodovane subjektivnosti i uniformnih tendencija kolektivnoga jezika. To ujedno znači da se ona naposljetku izlaže pritisku vremena. Ako se društveni karakter jezika uvlači u svaku poru individuacije, nijedna strategija modernoga umjetnika, ma kako radikalna ili nijansirana, ne može izmaći tendencijskom oblikovanju: "Jezik je, prema vlastitoj objektivnoj supstanciji, društveni izraz i tamo gdje se kao individualan oštro odvojio od društva. Promjene koje mu se u komunikaciji događaju sežu do u nekomunikativni materijal pisca. Ono što u upotrebi biva na riječima i jezičkim formama pokvareno, dospijeva oštećeno u povučenu radionicu. A tamo se istorijske štete ne daju reparirati. Historija ne samo da tangira jezik nego se događa usred njega." TheOdor Adorno, Minima moralia: refleksije iz oštećenog života, Veselin Masleša, Sarajevo, 1987., str. 218-219. Utoliko je Šimićevo odbacivanje nijanse, ako i nije promišljeno ili strateški koncipirano, upisano u njegov kritički i poetički diskurs.

26 A. B. Šımı́́, "Usamljenost duha", u: Sabrana djela, Proza II, August Cesarec, Zagreb, 1988., str. 228.

27 Isto, str. 229.

28 A. B. Šımí́, "Namjesto svih programa", u: Sabrana djela, Proza II, August Cesarec, Zagreb, 1988., str. 225. 
piše: "Čovjek osjeća jer je čovjek i čovjek misli jer je čovjek."29 Tako se stvara dojam neposrednosti. Ono što se prozire, što se uopće može vidjeti, nije uvid, nego upravo nedostatak uvida koji se ničim ne dopunja. Radovan Vučković primjećuje: "Šimićeva kritika, i onda kad se odnosila na premeravanje kulturne okoline, bila je direktan izraz njegovog ličnog raspoloženja, stanja njegove prirode u nekom određenom trenutku, i zato se nije uzdizala do prave stvaralačke objekcije za sebe." ${ }^{130}$ Nemec je na istome tragu: "Šimićeve kritike zanimljive su i u svojoj realizaciji. Nastale često kao rezultat trenutnog raspoloženja - one su dokument stanja duha i izraz nezadovoljstva književnom situacijom."31

Proturječno razumijevanje Šimićeve kritike, kao izraza neposrednosti ili prirodnoga stanja, nužan je rezultat nedostatka dokaza. Teorija ne može dokazivati tamo gdje dokazi nedostaju, ne može razvijati teze tamo gdje postoje samo parenteze, ne može dosljedno interpretirati tekstove sačinjene tek od skokova i naglih prijelaza. Stoga ostaje zakinuta u začetku i preostaje joj, poput Žmegača u svezi s jednim Šimićevim programskim tekstom, ustvrditi:

"Zacijelo nije potrebno dokazivati kako ove tvrdnje obiluju nesporazumima i logičkim protivrječjima. Međutim, povećali bismo broj nesporazuma kada bismo te riječi podvrgli racionalnoj analizi; jer one apeliraju isključivo afektivno i žele djelovati pojmovnom magijom. Ovakvu potenciranu afektivnost podržanu patetičkom vjerom u moć pjesničke riječi naći ćemo svagdje gdje se, na početku stoljeća, najavljuje borba tradiciji ili naprosto akademskoj rutini." 32

No, nedostatak dokaza proizlazi iz nedostatka uvida. Ovi nedostatci nisu samo simptomatični, nego i problematični. Stoga treba vrati-

29 A. B. Šimić, "Usamljenost duha", str. 228.

30 R. VučKović, nav. dj., str. 24. Ako i tretira izražajne karakteristike Šimićeva diskursa kao simptomatske, Vučković ipak u njima nalazi, sukladno temeljnomu nazoru svoje studije, određene razvojne elemente. Već će u sljedećoj rečenici ustvrditi: "Otuda je ona, pre svega, neobično značajna za praćenje geneze njegove umetničke ličnosti i duha, i može se posmatrat kao dnevnik (u širem značenju te reči) čoveka koji se stalno razvija, i dokaz je njegovih kriza i metamorfoza." Isto.

31 K. Nemec, nav. dj., str. 114. Ipak, i Nemec sljedećom rečenicom naznačuje određene strategije u Šimićevu diskursu koje nedvojbeno nadmašuju izraze trenutačnog raspoloženja: "Budući da je za Šimića i kritika osobna ekspresija, dakle umjetnička kreacija, veliku pažnju posvećivao je jeziku i stilu, težeći ponekad, forsiranjem začudnih konstrukcija, kalambura, obrata i paradoksa, i čistom efektu." Isto.

32 V. ŽMEgAČ, nav. dj., str. 85. 
ti pogled na problematična mjesta Šimićeva diskursa: nedostatkom uvida, dakle figure logičkoga poretka, ali i nedostatkom nadomjestka, dakle figure metafizičkoga poretka, ona ukazuju na krizu kritike kao kulturnoga koncepta moderne. Točnije rečeno: ona ukazuju na djelatno razumijevanje kritike kao krize i krize kao kritike. Ova će mjesta Koselleck prepoznati kao kulminacijske aspekte moderne epohe. ${ }^{33}$ Utoliko su proturječja Šimićeve kritike, ali i poetike, integralni dio jednoga procesa koji podjednako zahvaća modernu epohu i svjedoči njezinu zalasku. Otud proizlazi i teza rada: otpor i negacija Šimićeve kritike, s jedne strane, i neuspješni pokušaji uspostavljanja novih kriterija, s druge, nisu činjenice razvoja ili mijene, niti su činjenice preuranjene ili površne identifikacije, nego su žarište, i to jedino aktivno žarište moderne dijalektike. Otpor i negacija upravo iziskuju nemogućnost nadvladavanja: to je njihova završna poetička licenca. Šimićev anti i Šimićev $u$-topos pripadaju jednom te istom biću.

Procijepi i preobražaji, raskidi i skokovi, vezivanja i kristalizacije, sve su to simptomi Šimićeva diskursa, ali i jedne epohe na izmaku. Autentičnost više ne crpi svoju snagu iz vizije napretka i povijesnoga kontinuiteta i stoga se još jednom legitimira, ovaj put u onome novom kao radikalno negatorski položenomu spram onoga starog: "Kritike treba poubijati. Da što prije prođe vrijeme starih forma i dođe vrijeme novih forma." ${ }^{4}$ Šimić ovom rečenicom nesumnjivo epatira. Šok kao tehnika moderne avangarde nipošto nije tek odgovarajuća stilska ili strateška oznaka. Tehnika šoka prije svega ukazuje na nepredvidljivost, točnije rečeno na krizu predvidljivosti kao koncepta ljudski upravljane povijesti. ${ }^{35}$ Njome se provocira iznenađenje, preokret, izmicanje očekivanoga.

33 Proces sekularizacije Koselleck vidi kao dijagnostičku i prognostičku paradigmu koja mijenja eshatološku narav srednjega vijeka. Trenutci krize ujedno označavaju i krizu paradigme historijskoga procesa - u tim se trenutcima slika napretka pretače u sliku posljednjega suda: "Poznajemo proces sekularizacije, koji je eshatologiju pretvorio u povijest napretka. Ali podjednako su, svjesno i s namjerom, elementi božanskog suda i Posljednjeg dana pripojeni samoj povijesti, prije svega u pogoršanim kritičkim situacijama." REINHART KosELLECK, Critique and Crisis: Enlightement and the Pathogenesis of Modern Society, The MIT Press, Cambridge, Massachusetts, 1988., str. 10.

34 A. B. Šımı́́, "Juriš", u: Sabrana djela, Proza II, August Cesarec, Zagreb, 1988. str. 232.

35 O ovome konceptu govori Blumenberg: "Transfer strukturalne sheme estetskog, teorijskog, tehničkog i moralnog napretka u kolektivnu ideju jedinstve- 
S druge strane, epatiranje upućuje na procijep između mogućega i stvarnoga koji se više ne da strateški premostiti, niti razumski anticipirati. ${ }^{36}$ Nema dvojbe da se Šimić nalazi i stvara upravo u ovome procijepu. Razlika između pobijati i poubijati insinuira jedva vidljivu, rafiniranu, i stoga drastičnu krizu u komuniciranju kolektivnoga diskursa. Veze su pokidane i moguće je tek izdaleka prizvati moć koja objedinjuje. Reći će: "Ali, o kako smo još daleko od ideala. On je tako daleko da ga oči preko svih daljina jedva mogu da ugledaju. On je tako daleko da se čini kao da i ne postoji nigdje u cijelom vremenu. ${ }^{37}$ Procijep je za Šimića činjenica, fizički zakon iz kojega proizlazi ultimatum: "ili će postojati vrijednosti koje jesu ili vrijednosti koje nisu". ${ }^{38}$ On je ujedno i kategorički imperativ stvaralačkoga duha koji je, kako priznaje u svome manifestnom tekstu, tako usamljen, zatvoren pritiskom izvana da je njegov jedini glas vrisak. ${ }^{39}$

Ovo je već jasniji argument Šimićeve modernosti. Kada pjesnik poziva instancu doživljaja, koja je previše nova da bi bila nastavak starih, ${ }^{40}$ on se, s jedne strane, poziva na moć subjekta da se odnosi isključivo na sebe, a s druge, na pravo subjekta da kritizira sve osim sebe. Ove dvije instance dakako predstavljaju esencijalni poriv novovjekog racionalizma - da se, prema Fichteu, subjekt de facto bespredmetno ustoliči kao apsolutno jastvo, te da se, na sljedećemu stupnju i prema Kantu, de jure normira u čistoći kritike.

Nužna sloboda koju je moderni subjekt otkrio kao svoju nultu povijest na suveren način upravlja njegovom neposrednošću: ona se naime

ne povijesti podrazumijeva da čovjek vidi sebe kao jedinog odgovornog u ovom totalitetu, da uzima sebe kao onog koji 'pravi povijest'. Tako on može učiniti mogućim dedukciju povijesnih pokreta iz samo-razumijevanja racionalnog, demijurškog, ili pak stvaralačkog subjekta." Hans BlumenBerg, The Legitimacy of the Modern Age, The MIT Press, Cambridge Massachusetts, 1983., str. 33-34.

36 Iz ovoga procijepa Koselleck proriče sudbinu novoga vijeka: "Moja teza glasi da se u novome vijeku stalno povećava razlika između iskustva i očekivanja, točnije, da se novi vijek tek može razumjeti kao novo vrijeme otkako su se očekivanja sve više počela udaljavati od dotadašnjih iskustava." REINHART Koselleck, Vergangene Zukunft: Zur Semantik geschichtlicher Zeiten, Suhrkamp, Ffm, 1979., str. 359.

37 A. B. Šımić, "Usamljenost duha", str. 228.

38 A. B. Šımić, "Juriš", str. 230.

39 A. B. Šımić, "Usamljenost duha", str. 229.

40 A. B. Šımić, "Juriš", str. 231. 
zbog svoje radikalne položenosti prema unutarnjemu potvrđuje jedino u radikalnoj suprotstavljenosti prema onomu vanjskom. Drugim riječima, sve ono što ugrožava autoritet refleksije, sve ono što prijeti da posreduje između subjekta i njegova odraza u umu, opredmećuje se kao privid kojega treba razotkriti i odbaciti. ${ }^{41}$ Za Šimića nema sumnje: privid se očituje naknadnom, dakle, lažnom neposrednošću, a razmjeri se njegove laži mjere količinom posredovanoga prisustva u privatnoj sferi. Šimićeva radikalna negacija žurnalizma ${ }^{42}$ počiva upravo na ovim pretpostavkama: budući da, kako kaže, novinari ne prave novine, nego novine prave novinare, on nije potpun čovjek, on je ili neki instrument svojih vlasnika ili je nešto anonimno, i to ga čini sveprisutnim:
"Reporter je posvudan: kod ubistava, samoubistava, tučnjava, galama, kra- vala, skandala, slava, svađa, krađa, nedaća, nesreća, parnica, osuda - pravije rečeno, on rijetko tu za se neiskazanu sreću da se nađe kod takog događaja, nego gotovo uvijek doleti post festum, ali opiše sve tako kao da je bio nazo- čan od početka do kraja." ${ }^{13}$

Anonimnost i sveprisutnost su, dakle, uprizorenja novina i novinara, odnosno, kako pjesnik kaže "ove velike sile u koju je danas najopasnije dirati"44 i nisu to nimalo slučajna i glavna uprizorenja metafizičke infrastrukture - Šimićev je antižurnalizam naime ovjeren prosvjetiteljskim zahtjevom za oslobođenjem subjekta od dogmatske diktature privida, s tom razlikom da je religijsku dogmatiku zamijenila svjetovna. ${ }^{45}$ Utoliko je Šimićev antižurnalizam najuvjerljiviji kao antidogmatizam, u njemu se moderni subjekt potvrđuje kao autentična kritička snaga - u njemu Šimić stupa u dijalog s Blochovom kritikom aktualnosti koja ne može pružiti ništa osim klišeja jučerašnjice, ${ }^{46}$ ali i s Krausovom zastrašujućom dijagnozom duha vremena

41 Usp. Jürgen Habermas, Filozofski diskurs moderne, Globus, Zagreb, 1988., str. 7-26.

42 Radikalno negatorski stav spram žurnalizma Šimić očituje u nizu eseja: "Ekspresionizam i svjedočanstvo", "O kritici", "Journaille", "Žurnalizam", "Karl Kraus", "Novinstvo", "Literatura", "Autoreklama".

43 A. B. Šimıć, "Žurnalizam", str. 200.

44 Isto, str. 199.

45 Evo jedne rečenice koja nedvosmisleno izriče taj zahtjev: "Snaga je novina valjda u tome da čitač vjeruje kao da je sve što čita u njima objektivno i istinito, a ne da je u svakoj riječi izdavačev interes." (Isto, str. 221).

46 Šimićeva se kritika žurnalizma u bitnim crtama podudara s Blochovim ontički koncipiranim uvidima o fenomenu aktualnosti, bez obzira na to što kod poto- 
izrečenoj u Posljednjim danima čovječanstva: sve što se događa, zbiva se samo za one koji to opisuju i za one koji to ne doživljavaju. ${ }^{47}$

Upravo Krausova snažna i minuciozna analitička svijest daje zamah Šimićevoj kritici. U svome eseju o Krausu, on poantira da:

"reporteri svaki dan sve manje kazuju što je bilo nego prikazuju, slikaju, pjevaju što je bilo ... To miješanje informacije i fantazije, reportaže i poezije, žurnalizma i duha, koji tako pomiješani budu današnji žurnalizam, Krausu je mnogo gora pojava nego novinarsko iskrivljavanje ili prećutavanje istine, laganje, primanje mita, ucjenjivanje; jer što je korupcija 'prema svinjariji koja pjeva pjesme u svim rubrikama' (Kraus, Die Fackel)."${ }^{148}$

I zaključuje: umjetnost za se, žurnalizam za se. ${ }^{49}$ Ili žurnalizam ili duh, dakle. Ili informacija ili fantazija. Nije ovdje tek riječ o apologiji imaginacije kao izvanvremene kategorije, ${ }^{50}$ nego je prije svega riječ o ponoru iz kojega izvire stvaralačka i kritička energija modernoga pjesnika: on, naime, ne želi uzurpirati, on želi antagonizirati. Utoliko Simićeva kritika ostaje autentična samo kao negacija, ona zapravo

njega oni imaju prvenstveno projektivni smisao. Postoje barem dvije rečenice u Blochovom opusu koje bi Šimić mogao citirati u svojoj polemici s Bublićem i Parmačevićem: "Ali žurnalist koji samo aktuelno žurno posmatra i, kao službenik, referiše događaje - koliko je puta i on sam tek prodata radna snaga u pogonu kad ne sme da prozre stvar, da se ne bi spotakao i sam postao nepotreban u blizini dnevnih novina; takozvano saodlučivanje je ovde svakako još retko ... Već i zato što, kako kaže Česterton, moraju da prebrzo obrađuju svoju materiju, dakle upravo usled toga što žure da budu aktuelni, oni zaostaju za svojim vremenom, pa zbog toga nemaju šta da pruže osim klišea jučerašnjice." ERNST BLoch, Experimentum mundi, Nolit, Beograd, 1980., str. 34-35.

47 Još snažnije zvuči osuda izrečena u predgovoru: "Kako li je duboko pojmljivo otrežnjenje epohe koja se, nikad sposobna za doživljaj i za predodžbu doživljenoga, ne da pokolebati čak ni svojim slomom, ne mareći za kaznu baš kao ni za čin, ali ima dovoljno samoočuvanja da začepi uši pred fonografom svojih herojskih melodija i dovoljno samopožrtvovnosti da ih u danom slučaju iznova zapjeva." Karl Kraus, Posljednji dani čovječanstva, Disput, Zagreb, 2015., str. VIII.

48 A. B. Šımı́́, "Karl Kraus", str. 187.

49 Isto.

50 O eroziji pripovjedačke imaginacije uslijed novonastalih okolnosti i zahtjeva tehničke civilizacije govori i Benjamin, vidi eseje "Pripovjedač" i "Kriza romana", u: Walter Benjamin, Estetički ogledi, Školska knjiga, Zagreb, 1986., str. 166-193. Kraus ide i dalje, tvrdi: "Dokument je figura, izvještaji se izdižu kao likovi, likovi skončavaju kao uvodnici; feljton je dobio usta koja se monološki glasaju; fraze stoje na dvjema nogama - ljudi su zadržali samo jednu." K. KRAUs, nav. dj., str. VIII. 
može postojati samo kao negacija, to je njezin edipovski paradoks, čime se dolazi do druge teze: Śimićeva je modernost sposobna ostvariti se, ali samo po cijenu vlastite propasti. Ne samo da otpor i negacija iziskuju nemogućnost konkretizacije novih načela, nego i, povratno, nemogućnost moderne iziskuje otpor i negaciju kao apriorni kritički jezik - to je njezina prvotna poetička licenca. Čim je riješio Sfinginu zagonetku, čim je dakle stekao autentičan uvid, umjetnik je pokrenuo sudbinski proces koji će tu autentičnost dokinuti. Preciznije rečeno, bez obzira na to što je propast Šimićeva modernizma ugrađena u njegovu sudbinu, iz razloga koji će se navesti, ona se mora proživjeti da bi bila stvarna, da bi se dogodila, mora se doživjeti. Ova se pseudoaktualizacija, u Šimićevu slučaju, odvija na tri međusobne povezane razine.

Kao prvo, potrebno je uočiti kako niski stupanj kritičke zrelosti, dakle sasvim konkretan razlog, onemogućava aktualizaciju Šimićeva otpora. Ove je činjenice svjestan i sam autor: "Nemoć nas mladih, cijele ove naše literarne generacije koja se rodila (otprilike) zajedno s novim stoljećem, pokazuje se i u našim kritikama, u našim teorijama. Hoću reći: i u tom što zapravo nemamo kritike, nemamo teorijâ." ${ }^{51}$ Ono što nedostaje na ovoj razini dolazi izvana. Manjak kritike i teorije o kojoj govori Šimić predstavlja svojevrsno činjenično stanje. Ali, u isto vrijeme, ono pripada kulturi. Za Šimića nema sumnje - jedino iz kulture trebaju proizaći snage koje nadilaze status quo: "Činjenica je da je kultura opća težnja ljudskog duha od njegova prvog početka do danas sili nas da mislimo da je ona baš smisao naš zemaljski. Mi stvaramo kulturu, mi idemo prema svojem zemaljskom smislu."52 Kultura je ovdje iskonska smislotvorna snaga, imanentna ljudskome duhu i njegovu stvaralačkome nagonu. Utoliko se nemoć o kojoj govori Šimić tiče nacrta kritičke i poetičke drugosti koja na ovoj razini još iziskuje legitimaciju, traži zajednički jezik, makar tako što će ga negirati. Pjesnik ovdje traži iskupljujuća svojstva pjesničkoga jezika: kritika i poetika su tropocentrični.

No, u tom slučaju, ono što nedostaje i ono što iziskuje legitimaciju pripada kulturi. Manjak kritike i teorije ne dolazi izvana, nego je proizvedena $\mathrm{u}$ istom obzoru u kojem treba proizvesti viškove kritike i teorije. Kultura kao opća težnja ljudskoga duha unaprijed postulira jedno kretanje prema smislu koje svakim svojim uprizorenjem potvr-

51 A. B. Šımić, "Pisci u Zagrebu", str. 353.

52 A. B. Šımı́, "Usamljenost duha", str. 228. 
đuje pripadnost kulturi. To ujedno znači da su otpor i negacija uvijek već upisani u diskurzivni rad. Svijest je o nemoći sudbinski biljeg modernoga umjetnika koji njegov diskurs ujedno potvrđuje i isključuje. Njegova je vizija samotnoga stvaratelja, genija, demijurga sročena $s$ kolektivnim sredstvima koja su mu na raspolaganju. Njegovo je otpadništvo kulturna, dakle, konvencionalna činjenica. Ako je njegova snaga imaginacije antagonistična spram svake konvencije, njegov je čin pisanja konvencionalan. Drugim riječima, postuliranjem kulture stvaranja drugosti, Šimić zanemaruje one sustave kontrole koji djeluju iznutra, u samome diskursu. ${ }^{53}$ Nemoć zrcali pravila diskursa moći kao onoga mehanizma isključivanja koji svakom artikulacijom konstituira svoje drugo. Kontrakultura je zapravo inačica službene kulture, baš kao što je kritika inačica poetike, a nemoć postulat moći.

Naposljetku, nemoć pogađa Šimićevu kritiku žurnalizma istom snagom kojom pogađa njegovu poetiku antižurnalizma. Njegovo uporno imenovanje razlika između činjenice i fantazije, reportaže i poezije, žurnalizma i duha, umjetnosti i obrta, istine i laži previđa da je ta razlika već upisana u jedan te isti mehanizam. Šimić inzistira na nominalističkoj distinkciji pokazujući tako da ne razumije povijesnu prirodu odnosa privatnoga i kolektivnoga diskursa. Njegova apologija umjetničkoga dostojanstva iziskuje najamnu snagu žurnalizma, bez nje nije moguća. Napor očuvanja slobodne imaginacije stoji spram otpora informaciji i reportaže kao nemoć kritike spram moći stvaranja: oni se, naime, zrcale.

No, Šimić ne ostaje tek pri imenovanju razlika. Za njega su ove razlike konstitutivne, načelne, i posjeduju stvarnost izvan nominalnoga

$53 \mathrm{O}$ njima govori Foucault u uvodnome predavanju na Collège de Franceu: nemoć zrcali pravila diskursa moći kao onoga mehanizma isključivanja koji svakom artikulacijom konstituira svoje drugo (usp. Michael FoucAult, Poredak diskursa, Karpos, Loznica, 2007., str. 17-28). O tome još u: MichaEL FoucAult, Moć, znanje: odabrani spisi i razgovori: 1972-1977, Mediterran Publishing, Novi Sad, 2012. Habermas u Javnom mnijenju ide još dalje, on će odnos reprezentativne javnosti tradicionalne vladavine prema potisnutoj kontrakulturi prokazati kao nužno dihotomijski: onaj tko je pripadao kontrakulturi, naime, morao se kretati i izražavati u jednome sasvim drugom univerzumu. Habermas, dakle, osim mehanizma isključivanja, koji unaprijed obeznačuje aktualizaciju otpora, nalazi i mehanizam potiskivanja koji će aktualizaciju otpora ipak učiniti mogućom. Usp. Jürgen Habermas, Javno mnjenje: istraživanje u oblasti jedne kategorije građanskog društva, Mediterran Publishing, Novi Sad, 2012. 
obzora. Na ovoj se razini diskurs povlači iz opticaja: negacija zajedničkoga jezika postaje nemogućnost zajedničkoga jezika. Ako se na prvoj razini činjenica i fantazija, kritika i poetika potvrđuju tako što se negiraju, na ovoj se oni potiru. Drugost se hipostazira: ili će postojati vrijednosti koje jesu ili vrijednosti koje nisu. Šimić inzistira na ovoj fundamentalnoj distinkciji i tako žarište moderne dijalektike pretvara u "čelično kućište i čvrst razvojni zakon". ${ }^{54}$ Kada u polemici sa Stjepanom Parmačevićem uočava razliku između događaja i novinarove reakcije zaključujući da potonja nema po sebi vrijednost, jer da ima "tek malo od važnosti koju je imao događaj, ona ne bi prošla s njime", 55 Šimić zapravo propušta uočiti dijalektičku narav javnoga mnijenja koja u jednakoj mjeri proizvodi svoju bit i biva proizvedena njome. Kao i kod Krausa, Šimićeva kritika žurnalizma počiva na predodžbi neposredovane događajnosti koju ugrožava naknadna reakcija novinara. Ono što na ovoj razini nedostaje jest pristup istini, točnije rečeno, neposredovan i neiskrivljen pristup istini o stvarima. Pritom ovdje nije riječ o devijaciji Kantova nauka, nego o hipostazi bezinteresnoga stvaranja. Vođen interesom, novinar iskrivljuje događaj, dok će umjetnik, u svom kretanju ka smislu, omogućiti pristup istini, makar u čisto formalnom stanju, stoga: "Stvaralački duh kulture je usamljen, izgubljen u vrtlogu materijalnih težnja." ${ }^{56}$

Tek se upojedinjenjem kritika i poetika mogu legitimirati kao iskonske stvaralačke snage kulture. Samo tako se smislotvorno kretanje lišava posredovanih i iskrivljenih predodžbi. Naravno, pritom se usput lišava i legitimacijskih moći: s obzirom na nužnu mjeru posredovanja u postupku legitimiranja, upojedinjeni diskurs može tek, nemoćno i iz daljine, istaknuti vlastiti stvaralački i kritički zahtjev. Biti drukčiji za Šimića znači biti sâm, a to onda znači i biti obesnažen. Kritika koja hoće biti neposredna i nije kritika, stoga se njezina izdvojena pozicija ili mora ponovo uključiti u kulturni pogon, ili se mora uporno i dosljedno trošiti u negaciji.

No, to nije najdalekosežnija posljedica Šimićeve hipostaze. Inzistirajući na isključivo proizvođačkome načelu diskursa, Šimićeva poetika antižurnalizma nužno postaje logocentrična. Na taj način njezin

54 Peter Koslowski, "Supermoderna ili postmoderna? Dekonstrukcija i mistika u dvjema postmodernama", u: Republika, br. 7-8, Zagreb, 1993., str. 100.

55 A. B. Šımı́́, "Journaille", u: Sabrana djela, Proza II, August Cesarec, Zagreb, 1988., str. 274.

56 A. B Šımı́́, "Usamljenost duha", str. 228. 
potencijal ostaje jednostran i gubi moć preobrazbe. Uvidi koji joj nedostaju zapravo su uvidi koji je omogućuju. Uporno razotkrivanje lažnih neposrednosti zastaje na granici koju je iscrtao sam autor. Umjetnost ne želi uzurpirati jer ne može uzurpirati: prostor je već zauzet. Zato se povlači u gordu samoću, u imaginaciju, zato se opire, negira, antagonizira. Zato joj preostaje tek konstatirati da:

"Bilo bi ... krivo reći da bismo mi danas mogli biti bez novina. Premda ponajprije novinske agencije, a onda opet novine, izvrću vijesti kako im se sviđa, mi ipak danas bez vijesti o događajima u svijetu ne možemo biti. Ne, mi danas, kako ono netko reče, ne možemo biti bez novina kao ni bez engleskih zahoda." ${ }^{27}$

Prijeteća moć stvarnosti i njezini interesom iskvareni protagonisti ovdje se više ne mogu iskupiti načelnom izdvojenošću kritičke i poetičke instance. Preostaje još jedino uporno i dosljedno uzmicati, povlačiti se. No, u refleksu povlačenja poetika za sobom povlači krizu poiesisa, baš kao što kritika za sobom povlači krizu kritike. Na taj način i njihov načelni status postaje upitan. Preostaje inzistirati na načelu stvaratelja, na dostojanstvu umjetnika: na ovoj je razini Šimićeva kritika egocentrična. Novinar je ništavan, veli pjesnik u polemici s Bublićem i Parmačevićem, jer nije stvaratelj, jer prodaje tek vlasnikovo mišljenje, ${ }^{58}$ baš kao što kritika:

"... ne može u sebe primiti neposredan doživljaj - već zbog toga jer je on u svojoj potpunoj nedokučljivoj dubini neizreciv: u bilo kojem drugom materijalu ... nego što je materijal umjetničkog djela. I sve kad bi on bio izreciv - jedna apsolutna nemogućnost već zbog toga šta sada dolazi u obzir posve drugi individuum i nemogućnost da bude ponovljen isti doživljaj i u samom istom umjetniku koji je prvi put to djelo stvorio, dakle, ako to sve dopustimo, čemu ipak prevod toga djela u drugi materijal, to ponovljenje ... Kritika je samo onda to ako je umjetnost i filozofija." 59

Ovdje je Šimić dosegao najvišu točku svoga modernizma, ovdje je na Sfingino pitanje pjesnik odgovorio čovjek i tako pokrenuo sudbinski pad. Subjekt je ovdje jedina garancija vlastite neposrednosti, baš kao što rani Lukacs postulira u svojoj knjizi Duša i oblici. ${ }^{60}$ Ako je doživ-

57 A. B. Šımí́, "Journaille", str. 279.

58 Isto, str. 266-273.

59 A. B. Šımić, "O kritici", u: Sabrana djela, Proza II, August Cesarec, Zagreb, 1988., str. 311.

60 Usporedi Lukácseve primjedbe o eseju i esejistu: "...pesnička tvorevina dobija od sudbine svoj profil, svoj oblik; oblik se tamo uvek pojavljuje samo kao sudbina; u spisima esejista oblik postaje sudbina, sudbonosno načelo." GYörGY LukÁcs, Duša i oblici, Nolit, Beograd, 1973., str. 41. 
ljaj neizreciv osim u umjetničkoj riječi, onda on ili prethodi stvaratelju i ima vlastitu neposrednost ili ne postoji dok se ne izrekne, a u tom slučaju subjekt ne posjeduje vlastitu neposrednost.

Ovaj paradoks moderni umjetnik razrješava procesualno: tako što se povlači u načelnu usamljenost duha. Onoga časa kada je njegova hipostaza stvaralačkoga čina delegitimirana, on se okreće sebi samome. Na taj se način, reći će Hegel u svojoj kritici Kanta i Fichtea, duh otuđio od sebe samoga jer je od uma stvorio tek idola, refleksiju je krivo postavio na mjesto uma i time je nešto konačno uzdignuto do apsolutnoga ${ }^{61}$ Drugim riječima, čim je moderni umjetnik radikalno odbacio ono čime se posreduje, otpisujući to kao lažno i neautentično, on je u konačnici vlastitu neposrednost učinio lažnom i neautentičnom. Ova je aporija utisnuta u moderno djelo, i još više: ona ga autorizira, i to barem dvostruko.

S jedne strane, negirajući važnost intersubjektivne prakse moderni je subjekt postao jednostran i radikalnost njegove kritike nužno ostaje autentična samo kao negatorska. S druge strane, izolirajući se od društva u svoj vlastiti neprobojni svijet, primjećuje Eagleton u tekstu Kapitalizam, modernizam, postmodernizam, rad modernista paradoksalno reproducira, pa čak i intenzivira, samu iluziju o estetskoj autonomiji koja označava poredak protiv kojega se bori. ${ }^{62}$ Tako se on izručuje sudbini, onoj istoj čiju je anonimnost i sveprisutnost razotkrio kao privid.

$\mathrm{Na}$ taj način, naposljetku, pjesniku upravo sudbinski izmiču uvidi. On ih ničim ne nadomješta, i može tek jamčiti za njih dostojanstvom stvaraoca. Njegova kritika žurnalizma isprva zastaje na granici poetičkoga jezika, zatim na granici upojedinjenoga stvaralačkog čina, i konačno, na granici samoga stvaraoca. ${ }^{63} \mathrm{Na}$ ovoj posljednjoj granici

61 Usp. J. Habermas, Filozofski diskurs moderne, str. 27. Na komplementaran način treba razumjeti i Schillerovu kritičku projekciju stvaralačkoga čina. On će naznačiti da moderna umjetnost ne smije zahvatiti samo individuu, nego mora preobraziti životne forme koje odjeljuju individue. Pritom nije slučajno da su njegovi besprijekorno sročeni uvidi prvotno objavljeni u novinama - oni su dokaz suodnosnosti privatnoga i javnoga jezika (Usp. FrIEDRICH Schiller, O estetskom odgoju čovjeka u nizu pisama, Scarabeus - naklada, Zagreb, 2006.).

62 Usp. Terry Eagleton, "Kapitalizam, modernizam, postmodernizam", u: Zlatko Kramarić (prir.), Književnost, povijest, politika, Svjetla grada, Osijek, 1998., str. 71-90.

63 U sjajnoj studiji o hrvatskom ekspresionizmu Milanja govori o ekspresionističkoj ideji čovjeka kao generičkoga bića kojom je zahvaćen i Šimić: "Valja 
nije moguće proizvoditi uvide, tek aporijsku viziju ideala $\mathrm{i}$ istine, te potpunu negaciju žurnalizma. Uistinu, Šimićev antižurnalizam, s jedne strane, stalno zastaje na subjektivnoj i partikularnoj kritici, a s druge, stalno poseže za argumentum ad verecundiam, za citatima i usporedbama. Stoga, umjesto zaključka i u nedostatku uvida, teoriji preostaje jedino učiniti usporedbu:

Chesterton, koji se od svih modernista vinuo vjerojatno najviše $u$ eter, sasvim suvislo u svome Pravovjerju optužuje modernu znanost za sentimentalizam i determinizam jer smatra da: "pošto jedna neshvatljiva stvar stalno slijedi drugu neshvatljivu stvar, njih dvije zajedno nekako čine jednu shvatljivu stvar. Dvije nejasne zagonetke daju jedan jasan odgovor". ${ }^{64}$

Umjesto toga, Chesterton nudi etiku vilinske zemlje u kojoj "sunce sja jer je začarano",65 a oporučno ostavljenomu krilatom konju ne gleda se u zube. I sasvim sentimentalno i deterministički zaključuje: svaki je čovjek potekao iz priče, "a ako postoji priča, onda mora postojati i onaj tko priča priče". ${ }^{66}$ To je ono isto stvaralačko načelo na kojemu i Šimić inzistira. U Filozofiji o riječi on zahtijeva: "Treba da riječi misle ono što mi mislimo, a ne da one misle svoje, to će reći misli svojih stvarača." ${ }^{167}$ Stoga je njegova poetika poetika iste vilinske zemlje. U njoj pjesnik začaranom suncu vraća sve što je od njega dobio.

Stalno prizivajući stvaraoca, onoga tko priča priče, Šimić zapostavlja potisnutu, već stvorenu dimenziju priče: zato je dosljedan tek kao

pritom napomenuti da se Šimićeva teza o čovjekovu zemaljskom smislu koji se ispunjava kulturnim kreacionizmom, ne odnosi na čovjeka kao društveno biće, niti se odnosi na povijesnu ili društvenu projekciju, nego na utopijsku kategoriju 'duhovnog carstva na zemlji' (D, II: 228.), te usamljenosti i krhkosti kulture spram materijalističke opasnosti. Znači, Šimić ne barata pojmom čovjeka kao društvena bića, nego ekspresionističkom idejom čovjeka kao generičkog bića." (C. Milanja, "Utopijske značajke teorijskog uma hrvatskog ekspresionizma", u: Ekspresionizam u hrvatskoj književnosti i umjetnosti, Zbornik radova I. znanstvenog skupa s međunarodnim sudjelovanjem, C. MILANJA (ur.), Altagama, Zagreb, 2002., str. 43). Tako postulirana ideja vrijedi za modernog umjetnika sui generis.

64 Gilbert Keith Chesterton, Pravovjerje, Sion, Zagreb, 2001., str. 59.

65 Isto, str. 60.

66 Isto, str. 71.

67 A. B. Šımı́́, "Filozofija o riječi", u: Sabrana djela, Proza II, August Cesarec, Zagreb, 1988., str. 303. 
negator, zato se gubi u nedosljednim uprizorenjima, zato stalno korigira iskustvo, očekuje, koncipira, planira. "Kompozicija, cjelina - to je ono što me čini očajnim", ${ }^{68}$ priznaje u svome dnevniku. Ne treba nam bolji dokaz od pogleda na Šimićevu radnu bilježnicu.

$\mathrm{Na}$ obratnoj je stranici otkinuta plava korica, praznina je početne bijele stranice ispisana u raznim smjerovima i drugom tintom. Na prvoj stranici pjesnik govori o kinoplastici, o fantomu koji pleše: "kad umire on ostaje dalje, on, umnožen bezbroj puta ... nije li to malo čudo".69 Na drugoj strani ispisanoj čitkim Šimićevim rukopisom nalazi se pjesma Veliki ubijač s različitim inačicama stihova. Na trećoj je strani sve precrtano. Uporno tražeći čovjeka, pjesnik je našao tek zagonetku.

68 A. B. Šımı́́, "Dnevnik", u: Sabrana djela, Proza II, August Cesarec, Zagreb, 1988., str. 464.

69 A. B. Šımı́́, "Radna bilježnica", u: Sabrana djela, Proza II, August Cesarec, Zagreb, 1988., str. 503. 


\title{
Poetics of Anti-Journalism in A.B. Simic's Essays
}

\section{Summary}

\begin{abstract}
A. B. Simic's essayistic work is characterized by the usage of critical, polemical, programmatic and aphoristic devices in an unambiguous affirmation of the expressive nature of artistic creature and an unequivocal negation of poetic adequacy and ethical traditionalism. The unambiguity of critical and poetical utterances unveils a tendentious configuration of Simic's discourse. Such structuring is most clearly manifested in Simic's antagonistic attitude towards the concept and model of journalism which is understood in the author's perspective as a specified value. Using the dialectical insights of critical theory, especially those by $\mathrm{Ha}-$ bermas, Bloch's historical and philosophical insights, Foucault, Koselleck, and Terry Eagleton's literary theory, this paper aims to specify the connection between the principle and purposefulness of the modern discourse as a crucial fact, both in conceptualization and shaping of Simic's poetry of anti-journalism, as well as in understanding and shaping of modern discourse in general.
\end{abstract}

Keywords: anti-dogmatism; anti-journalism; critics; modernism; poetics. 